\title{
Pengaruh Jenis Ekstrak dan Konsentrasi ZPT Organik dalam Peningkatan Viabilitas Benih Kedelai (Glycine max L.) Kadaluarsa
}

\author{
The Effect Of Extrac Type and Concentration Of Organic PGR by Increasing Viability to \\ Expired Soybean Seeds (Glycine max L.)
}

\author{
Heru Septiadi ${ }^{1}$, Nanda Mayani ${ }^{2}$, Trisda Kurniawan ${ }^{2 *}$ \\ ${ }^{1}$ Mahasiswa Program Studi Agroteknologi, Fakultas Pertanian, Universitas Syiah Kuala \\ ${ }^{2}$ Staf Pengajar Program Studi Agroteknologi, Fakultas Pertanian, Universitas Syiah Kuala
}

\begin{abstract}
Abstrak. Penelitian ini bertujuan untuk mengetahui pengaruh jenis ekstrak dan konsentrasi ZPT organik dalam peningkatan viabilitas benih kedelai kadaluarsa. Penelitian ini dilaksanakan di Laboratorium Ilmu dan Teknologi Benih Program Studi Agroteknologi Fakultas Pertanian, Universitas Syiah Kuala, Darussalam Banda Aceh. Penelitian berlangsung dari bulan Agustus sampai September 2018. Penelitian ini menggunakan Rancangan Acak Lengkap (RAL) pola faktorial dengan tiga kali ulangan. Faktor yang diteliti ada dua faktor yaitu faktor jenis ekstrak dan konsentrasi. Faktor jenis ekstrak terdiri dari 3 taraf yaitu ekstrak jagung, ekstrak tomat, dan air kelapa. Faktor kedua yaitu konsentrasi yang terdiri dari 3 taraf yaitu, 20\%, $40 \%$ dan $60 \%$. Parameter yang diamati adalah daya berkecambah, kecepatan tumbuh, keserempakan tumbuh, dan berat kering kecambah normal. Hasil penelitian menunjukkan bahwa tidak terjadi interaksi yang nyata antara jenis ekstrak ZPT organik dengan konsentrasi yang berbeda dalam peningkatan viabilitas benih kedelai kadaluarsa. Pada parameter daya berkecambah, kecepatan tumbuh, dan keserempakan tumbuh nilai terbaik diperoleh pada perlakuan konsentrasi ekstrak jagung 20\%. Sedangkan pada berat kering kecambah normal nilai terbaik diperoleh pada perlakuan konsentrasi ekstak tomat $60 \%$.
\end{abstract}

Kata kunci : ekstrak, konsentrasi, tanaman kedelai

Abstrac. This research aims to study the effect of the type of extract and concentration of organic PGR to increase viability of expired soybean seeds. This research was conducted at the Seed Science and Technology Laboratory of the Agrotechnology Study Program at the Faculty of Agriculture, Syiah Kuala University, Darussalam Banda Aceh. This research had been conducted from August to September 2018. This study used a completely randomized design (CRD) factorial pattern with three replications. The factors studied were two factors: extract type and concentration. The type of extract factor consists of 3 levels namely corn extract, tomato extract, and coconut water. The second factor is the concentration consisting of 3 levels $20 \%, 40 \%$ and $60 \%$. The parameters observed were germination, growth speed, simultaneous growth, and normal sprout dry weight. The results showed that there was no significant interaction between the types of organic PGR extract with different concentrations. On the germination power parameters, growth speed, and growing similarity of the best values were obtained in the combination treatment of $20 \%$ corn extract concentration. While the normal sprout dry weight of the best values were obtained in the combination treatment of $60 \%$ tomato extract concentration.

Keywords: extract, concentration, soybean plants

\section{PENDAHULUAN}

Kedelai merupakan komoditas pangan dengan kandungan protein nabati tinggi dan telah digunakan sebagai bahan baku produk olahan seperti susu kedelai, tempe, tahu, kecap, dan berbagai makanan ringan lainnya. Di Indonesia, kedelai merupakan komoditas pangan terpenting setelah padi dan jagung. Komoditas ini digunakan untuk konsumsi pangan rumah tangga, industri, dan benih. Dalam 13 tahun terakhir, konsumsi kedelai dan produk olahannya cenderung meningkat. Pada tahun 2015, konsumsi kedelai mencapai 2,54 juta ton biji kering yang terdiri atas konsumsi langsung penduduk 2,3 juta ton, benih 39.000 ton, industri nonmakanan 446.000 ton, dan susu 49.000 ton (BPS, 2015). 
Dalam perkembangan pertanian, benih memiliki peran yang penting sebagai sistem penyalur atau pembawa teknologi baru. Beberapa teknologi baru (varietas baru) disampaikan ke petani melalui benih bermutu. Benih yang bermutu yaitu benih yang mempunyai mutu genetik, fisiologis, dan fisik yang bagus atau viabilitasnya masih baik (Hasanah, 2002).

Viabilitas benih adalah gejala hidup benih yang menunjukkan beragam fenomena fisiologis maupun biokimiawi. Daya berkecambah menunjukkan jumlah kecambah normal yang dihasilkan oleh benih murni dalam kondisi lingkungan tertentu pada jangka waktu yang sudah ditetapkan (Suwarno dan Hapsari, 2008).

Penurunan viabilitas benih kedelai secara cepat terutama disebabkan oleh tingginya kandungan protein dan kondisi lingkungan tropis dengan kelembaban yang tinggi. Protein merupakan kandungan kimia yang paling banyak dalam benih kedelai yang memiliki sifat mudah menyerap dan menahan uap air (higroskopis), sehingga berperan penting dalam peningkatan kadar air benih (Hasbianto, 2012).

Kartasapoetra (2003), menyatakan bahwa benih yang telah melewati masa anjuran pemakaiannya yang sudah di tentukan oleh produsen benih adalah benih yang sudah mengalami kadaluarsa.

Benih kedelai yang sudah kadaluarsa merupakan salah satu kendala yang dihadapi oleh petani Indonesia. Benih kedelai hanya mempunyai daya tahan penyimpanan selama 3 bulan dan tidak jarang benih dikonsumsi langsung oleh para petani. Benih yang sudah kadaluarsa akan mengalami kemunduran benih dan kualitas untuk dibudidayakan. Salah satu upaya peningkatan produktivitas benih kedelai yaitu dengan memanfaatkan benih kadaluarsa dengan memberikan perlakuan pada benih sebelum tanam (Suhaeni, 2007).

Zat pengatur tumbuh tanaman yaitu suatu zat organik yang bukan hara, yang mana dalam jumlah sedikit dapat mendukung, menghambat dan dapat merubah proses fisiologis tanaman (Abidin, 1993).

Media yang dapat digunakan sebagai ZPT organik adalah ekstrak dari buah tomat, ekstrak dari buah pisang dan air kelapa muda. Ekstrak dari buah pisang berfungsi sebagai koenzim pada beberapa reaksi metabolisme, sedangkan vitamin B6 berperan dalam sintesis dan metabolisme protein. Ekstrak tomat berfungi mempercepat pertumbuhan benih, hal ini disebabkan karena terdapat berbagai kandungan senyawa organik seperti karbohidrat, asam amino, dan hormon tumbuh, sedangkan air kelapa muda memiliki kandungan mineral, sitokinin, auksin, fosfor dan kinetin yang berfungsi mempercepat laju pembelahan sel serta pertumbuhan tunas dan akar (Fatimah, 2008).

Selain pemberian berbagai jenis ekstrak ZPT organik, perlu juga dilihat pada konsentrasi berapakah yang berpengaruh terhadap viabilitas benih kadaluarsa. Pemberian air kelapa muda dengan konsentrasi $30 \%$ pada periode inkubasi 24 jam dapat meningkatkan viabilitas dan vigor benih bengkuang kadaluarsa, sedangkan pada konsentrasi $15 \%$ dapat meningkatkan viabilitas benih kedelai kadaluarsa (Gunawan, 2004; Miranda, 1999).

Pemberian ekstrak organik pada benih adalah perlakuan pendahuluan menggunakan zat organik untuk benih dengan mengontrol imbibisi air pada potensial air yang rendah dari media imbibisi tersebut. Pemberian ekstrak jagung 50\% pada periode inkubasi benih 
selama 72 jam dapat meningkatkan viabilitas benih melon dan cabai kadaluarsa (Halimursyadah, et al., 2003).

Penelitian ini dilakukan untuk mengetahui pengaruh jenis ekstrak dan konsentrasi ZPT organik dalam peningkatan viabilitas benih kedelai kadaluarsa.

\section{METODELOGI PENELITIAN}

\section{Tempat dan Waktu}

Penelitian ini dilaksanakan di laboratorium Teknologi Benih Fakultas Pertanian Universitas Syiah Kuala Darussalam Banda Aceh. Penelitian dimulai dari bulan Agustus sampai September 2018.

\section{Alat dan Bahan}

Alat yang digunakan dalam penelitian ini mencakup blender, botol aqua, wadah plastik, germinator, aerator, kertas label, pisau, saringan santan dan gelas ukur. Sedangkan bahan yang digunakan dalam penelitian ini adalah benih kedelai kadaluarsa varietas anjasmoro sebanyak 900 butir, ekstrak jagung, ekstrak tomat dan air kelapa muda sebanyak $500 \mathrm{ml}$, serta media substrat kertas merang dan kertas label.

\section{Analisis Data}

Penelitian ini menggunakan Rancangan Acak Lengkap (RAL) pola faktorial dengan tiga kali ulangan. Perlakuan yang diteliti ada dua faktor yaitu faktor jenis ekstrak (E) dan konsentrasi (K). Faktor jenis ekstrak (E) terdiri dari 3 taraf yaitu $\mathrm{E}_{1}$ (ekstrak jagung), $\mathrm{E}_{2}$ (ekstrak tomat), dan $\mathrm{E}_{3}$ (air kelapa). Faktor kedua yaitu konsentrasi yang terdiri dari 3 taraf yaitu, $\mathrm{K}_{1}(20 \%), \mathrm{K}_{2}(40 \%)$ dan $\mathrm{K}_{3}(60 \%)$. Dengan demikian terdapat 9 kombinasi perlakuan. Masing-masing kombinasi perlakuan diulang sebanyak tiga kali. Untuk setiap satuan perlakuan terdiri atas 25 butir benih kedelai.

\section{Persiapan Benih}

Benih kedelai yang digunakan dalam penelitian ini berasal dari Laboratorium Teknologi Benih Fakultas Pertanian Universitas Syiah Kuala Banda Aceh. Benih tersebut merupakan benih yang sudah kadaluarsa yang telah mengalami kadaluarsa pada tahun 2014 dengan daya berkecambah 64\%. Benih tersebut lalu disortir dan dibersihkan untuk dijadikan bahan penelitian. Benih yang digunakan sejumlah 25 butir untuk setiap satuan percobaan. Kebutuhan benih dalam penelitian ini adalah 900 butir.

\section{Persiapan ZPT Organik}

Estrak jagung yang digunakan pada penelitian ini berasal dari jagung muda dengan berat total $1,5 \mathrm{~kg}$ untuk dijadikan ekstrak murni dan ekstrak tomat yang digunakan berasal dari buah tomat segar yang berwarna merah tidak berkerut dengan berat total $1 \mathrm{~kg}$ untuk dijadikan ekstrak murni. Jagung dan tomat dibersihkan lalu dipotong-potong dan dihaluskan dengan blender, kemudian disaring menggunakan saringan santan untuk mendapatkan ekstrak yang halus dengan hasil ekstrak untuk jagung $700 \mathrm{ml}$ dan tomat 750 $\mathrm{ml}$, lalu dicampur aquades sebagai pelarut, dan dimasukkan kedalam botol plastik dengan kosentrasi sesuai perlakuan $(20 \%, 40 \%$ dan 60\%). Sedangkan air kelapa diambil dari buah 
kemasakan sedang dengan ciri-ciri kulit buah berwarna hijau licin serta daging buah masih lunak, kemudian ditambahkan aquades untuk mendapatkan konsentrasi yang sama.

Untuk membuat ZPT organik dari ekstrak jagung dan tomat dengan kosentrasi $20 \%$ sebagai berikut : $(20 / 100) \times 400 \mathrm{ml}=80 \mathrm{ml}$, jadi untuk perlakuan E1 atau E2 dibuat dengan cara $(80 \mathrm{ml}$ ekstrak jagung atau tomat $+320 \mathrm{ml}$ aquadest). Kapasitas incubator yang digunakan adalah $400 \mathrm{ml}$, dimana dalam penelitian ini $20 \%$ dari total incubator diisi oleh ekstrak jagung, tomat, dan air kelapa muda dan sisanya yaitu sebesar $80 \%$ merupakan pelarut yaitu air (Halimursyadah et al, 2015).

\section{Inkubasi Benih}

Benih yang telah dipilih selanjutnya direndam ke dalam masing-masing konsentrasi ekstrak jagung, tomat, dan air kelapa muda untuk diinkubasikan. Kemudian dipasang aerator agar benih mendapat oksigen yang cukup. Inkubasi dilakukan selama 3 jam.

\section{Pengecambahan Benih}

Setelah dicuci, benih selanjutnya dikecambahkan menggunakan metode uji UKDdp (Uji Kertas Digulung dalam plastik) dengan kertas merang. Setiap satuan percobaan berisi 25 butir benih.

\section{Pengamatan}

Parameter yang diamati pada penelitian ini yaitu daya berkecambah, kecepatan tumbuh, keserempakan tumbuh, dan berat kering kecambah normal.

\section{HASIL DAN PEMBAHASAN}

\section{Pengaruh Jenis Ekstrak dan Konsentrasi ZPT Organik dalam Peningkatan Viabilitas Benih Kedelai Kadaluarsa}

Rekapitulasi hasil analisis ragam (Uji F) pengaruh perlakuan berbagai jenis ekstrak dan konsentrasi ZPT organik pada seluruh parameter disajikan pada Tabel 2.

Tabel 1. Rekapitulasi Uji F Pengaruh Perlakuan Berbagai Jenis Ekstrak dengan Konsentrasi yang berbeda pada seluruh Parameter yang diamati.

\begin{tabular}{|c|c|c|c|c|c|c|}
\hline \multirow{2}{*}{ Parameter } & \multicolumn{3}{|c|}{ Perlakuan } & \multicolumn{2}{|c|}{ F.hitung } & \multirow{2}{*}{$\mathrm{KK}(\%)$} \\
\hline & $\mathrm{E}$ & $\mathrm{K}$ & E X K & 0,05 & 0,01 & \\
\hline Daya Berkecambah (\%) & $0,32^{\text {tn }}$ & $0,34^{\mathrm{tn}}$ & $0,17^{\text {tn }}$ & 2.928 & 4.579 & 13,19 \\
\hline Kecepatan Tumbuh (\%) & $0,74^{\mathrm{tn}}$ & $0,39^{\mathrm{tn}}$ & $0,22^{\text {tn }}$ & 2.928 & 4.579 & 17,39 \\
\hline Keserempakan Tumbuh (\%) & $0,67^{\mathrm{tn}}$ & $0,11^{\text {tn }}$ & $0,57^{\mathrm{tn}}$ & 2.928 & 4.579 & 11,73 \\
\hline Berat Kering Kecambah Normal (g) & $2,34^{\text {tn }}$ & $0,42^{\text {tn }}$ & $0,6^{\mathrm{tn}}$ & 2.928 & 4.579 & 10,74 \\
\hline
\end{tabular}

Keterangan : tn : tidak berpengaruh nyata; E : ekstrak; K : konsentrasi; ExK : interaksi antara konsentrasi; KK : koefisien keragaman $(\%)$

Tabel 1 menunjukkan bahwa seluruh perlakuan, baik secara mandiri maupun interaksinya tidak berpengaruh nyata pada parameter-parameter yang diamati 


\section{Daya Berkecambah (\%)}

Hasil uji F menunjukkan bahwa pemberian berbagai jenis ekstrak ZPT organik dengan konsentrasi yang berbeda tidak berpengaruh terhadap daya berkecambah benih kedelai kadaluarsa. Rata-rata daya berkecambah benih kedelai kadaluarsa akibat pengaruh berbagai jenis ekstrak dan konsentrasi zpt organik dapat dilihat pada Tabel 2.

Tabel 2. Rata-rata Daya Berkecambah (\%) Benih Kedelai Kadaluarsa akibat Pengaruh Berbagai Jenis Ekstrak dan Konsentrasi ZPT Organik.

\begin{tabular}{ccccl}
\hline \multicolumn{2}{l}{$\begin{array}{l}\text { Jenis Ekstrak } \\
\text { ZPT organik }\end{array}$} & \multicolumn{3}{c}{ Konsentrasi } \\
Jagung & $\left(\mathrm{E}_{1}\right)$ & 66,67 & $60 \%\left(\mathrm{~K}_{2}\right)$ & $60 \%\left(\mathrm{~K}_{3}\right)$ \\
\hline \multirow{2}{*}{ Tomat } & $\left(\mathrm{E}_{2}\right)$ & $(54,83)$ & 62,67 & 62,67 \\
& & 64,00 & 54,67 & $(52,50)$ \\
\multicolumn{2}{l}{ Air kelapa $\left(\mathrm{E}_{3}\right)$} & $(53,23)$ & $(47,69)$ & 61,33 \\
& & 60,00 & 60,00 & $62,63)$ \\
& $(50.82)$ & $(50,78)$ & $(52,66)$ \\
\hline
\end{tabular}

Keterangan : ( ) Data setelah di transformasi menggunakan $\arcsin \sqrt{ } p$

Tabel 2 menunjukkan bahwa apabila menggunakan ekstrak jagung, daya berkecambah benih cenderung lebih baik terdapat pada konsentrasi ekstrak 20\%, apabila menggunakan ekstrak tomat, daya berkecambah benih cenderung lebih baik terdapat pada konsentrasi ekstrak 20\%, dan apabila menggunakan ekstrak air kelapa, daya berkecambah benih cenderung lebih baik terdapat pada konsentrasi ekstrak $60 \%$, walaupun tidak berbeda nyata dengan perlakuan lainya.

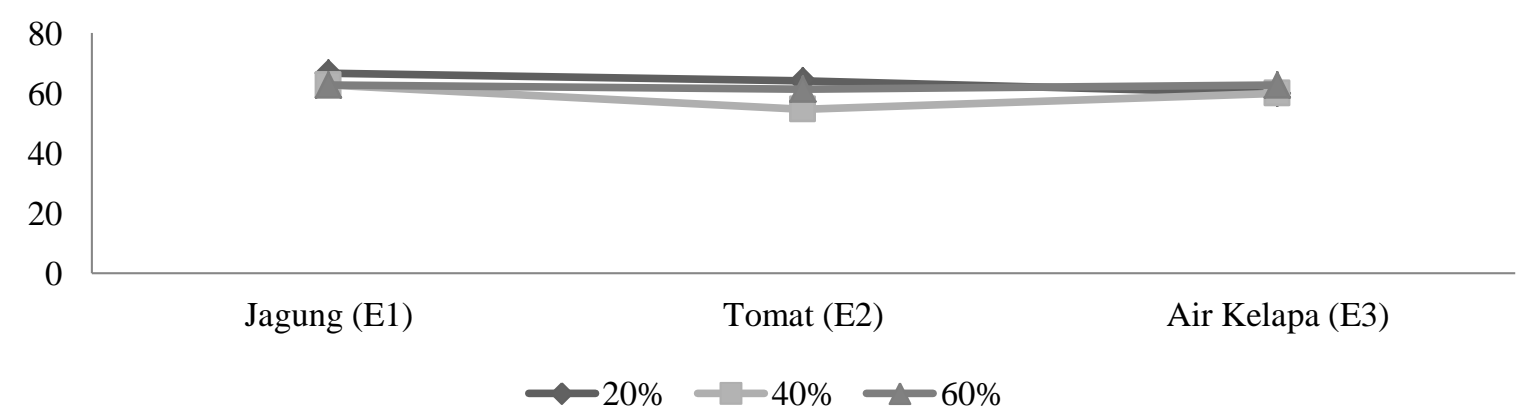

Gambar 1. Rata-rata Nilai Daya Berkecambah (\%) Benih Kedelai Kadaluarsa akibat Pengaruh Berbagai Jenis Ekstrak dan Konsentrasi ZPT Organik.

\section{Kecepatan Tumbuh (\%/etmal)}

Hasil uji $\mathrm{F}$ menunjukkan bahwa pemberian berbagai jenis ekstrak zpt organik dengan konsentrasi yang berbeda tidak berpengaruh terhadap kecepatan tumbuh benih kedelai kadaluarsa. Rata-rata kecepatan tumbuh benih kedelai kadaluarsa akibat pengaruh berbagai jenis ekstrak dan konsentrasi zpt organik dapat dilihat pada Tabel 3. 
Tabel 3. Rata-rata Kecepatan Tumbuh (\%) Benih Kedelai Kadaluarsa akibat Pengaruh Berbagai Jenis Ekstrak dan Konsentrasi ZPT Organik.

\begin{tabular}{|c|c|c|c|}
\hline Jenis Ekstrak & \multicolumn{3}{|c|}{ Konsentrasi } \\
\hline ZPT organik & $20 \%\left(\mathrm{~K}_{1}\right)$ & $40 \%\left(\mathrm{~K}_{2}\right)$ & $60 \%\left(\mathrm{~K}_{3}\right)$ \\
\hline Jagung $\quad\left(\mathrm{E}_{1}\right)$ & 3,30 & 3,11 & 3,10 \\
\hline Tomat $\left(\mathrm{E}_{2}\right)$ & 3,07 & 2,65 & 2,97 \\
\hline Air kelapa $\left(E_{3}\right)$ & 2,86 & 2,87 & 3,08 \\
\hline
\end{tabular}

Tabel 3 menunjukkan bahwa apabila menggunakan ekstrak jagung, kecepatan tumbuh benih cenderung lebih baik terdapat pada konsentrasi ekstrak 20\%, apabila menggunakan ekstrak tomat, kecepatan tumbuh benih cenderung lebih baik terdapat pada konsentrasi ekstrak 20\%, dan apabila menggunakan ekstrak air kelapa, kecepatan tumbuh benih cenderung lebih baik terdapat pada konsentrasi ekstrak 60\%, walaupun tidak berbeda nyata dengan perlakuan lainya.

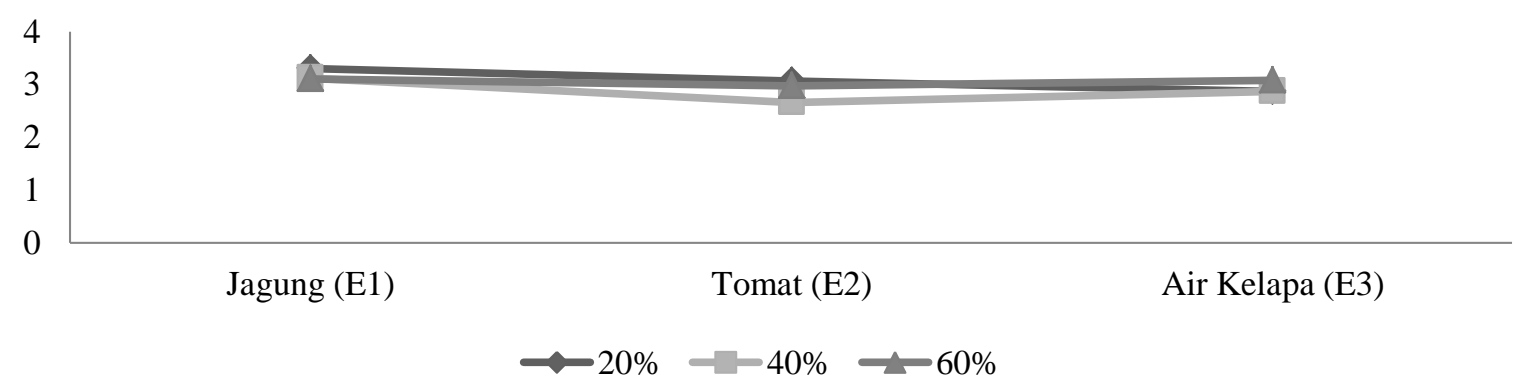

Gambar 2. Rata-rata Kecepatan Tumbuh (\%) Benih Kedelai Kadaluarsa akibat Pengaruh Berbagai Jenis Ekstrak dan Konsentrasi ZPT Organik.

\section{Keserampakan Tumbuh (\%)}

Hasil uji F menunjukkan bahwa pemberian berbagai jenis ekstrak zpt organik dengan konsentrasi yang berbeda tidak berpengaruh terhadap keserempakan tumbuh benih kedelai kadaluarsa. Rata-rata keserempakan tumbuh benih kedelai kadaluarsa akibat pengaruh berbagai jenis ekstrak dan konsentrasi zpt organik dapat dilihat pada Tabel 4.

Tabel 4. Rata-rata Keserempakan Tumbuh (\%) Benih Kedelai Kadaluarsa akibat Pengaruh Berbagai Jenis Ekstrak dan Konsentrasi ZPT Organik.

\begin{tabular}{|c|c|c|c|}
\hline Jenis Ekstrak & \multicolumn{3}{|c|}{ Konsentrasi } \\
\hline ZPT organik & $20 \%\left(\mathrm{~K}_{1}\right)$ & $40 \%\left(\mathrm{~K}_{2}\right)$ & $60 \%\left(\mathrm{~K}_{3}\right)$ \\
\hline Jagung $\quad\left(\mathrm{E}_{1}\right)$ & $\begin{array}{l}65,33 \\
(54,03)\end{array}$ & $\begin{array}{l}62,67 \\
(52,65)\end{array}$ & $\begin{array}{l}57,33 \\
(49,20)\end{array}$ \\
\hline Tomat $\quad\left(E_{2}\right)$ & $\begin{array}{l}60,00 \\
(50,78)\end{array}$ & $\begin{array}{l}52,00 \\
(46,16)\end{array}$ & $\begin{array}{l}57,33 \\
(49,27)\end{array}$ \\
\hline Air kelapa $\left(\mathrm{E}_{3}\right)$ & $\begin{array}{l}56,00 \\
(48,46)\end{array}$ & $\begin{array}{l}60,00 \\
(50,78)\end{array}$ & $\begin{array}{l}61,63 \\
(51,74)\end{array}$ \\
\hline
\end{tabular}

Keterangan : ( ) Data setelah di transformasi menggunakan $\arcsin \sqrt{p}$ 
Tabel 4 menunjukkan bahwa apabila menggunakan ekstrak jagung, keserempakan tumbuh benih cenderung lebih baik terdapat pada konsentrasi ekstrak 20\%, apabila menggunakan ekstrak tomat, keserempakan tumbuh benih cenderung lebih baik terdapat pada konsentrasi ekstrak 20\%, dan apabila menggunakan ekstrak air kelapa, keserempakan tumbuh benih cenderung lebih baik terdapat pada konsentrasi ekstrak $60 \%$, walaupun tidak berbeda nyata dengan perlakuan lainya.

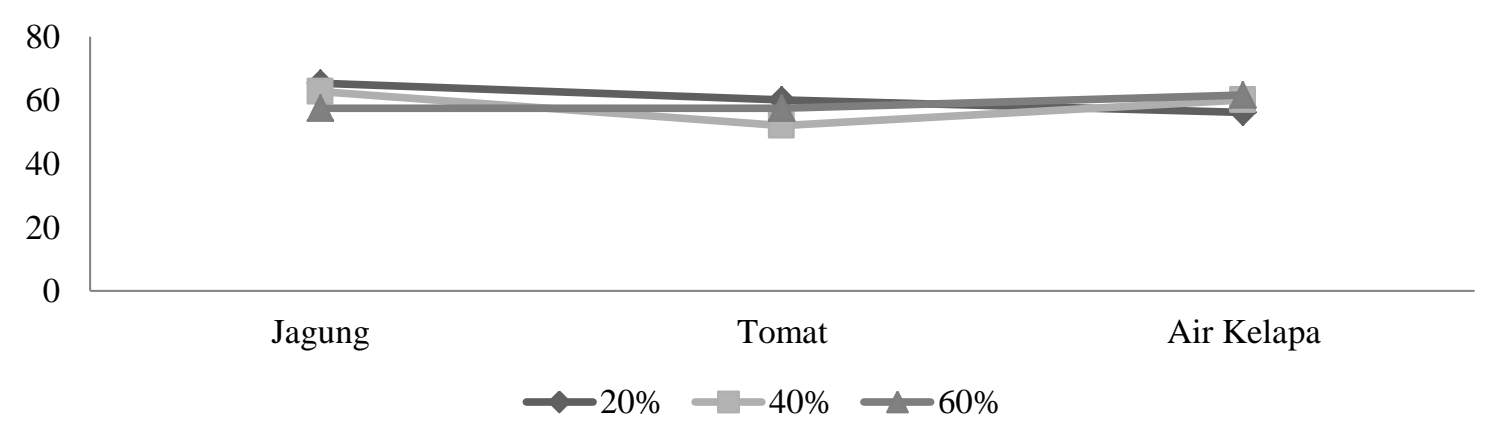

Gambar 3. Rata-tata Keserempakan Tumbuh (\%) Benih Kedelai Kadaluarsa akibat Pengaruh Berbagai Jenis Ekstrak dan Konsentrasi ZPT Organik.

\section{Berat Kering Kecambah Normal (g)}

Hasil uji $\mathrm{F}$ menunjukkan bahwa pemberian berbagai jenis ekstrak zpt organik dengan konsentrasi yang berbeda tidak berpengaruh terhadap berat kering kecambah normal benih kedelai kadaluarsa. Rata-rata berat kering kecambah normal benih kedelai kadaluarsa akibat pengaruh berbagai jenis ekstrak dan konsentrasi zpt organik dapat dilihat pada Tabel 9.

Tabel 5. Rata-rata Berat Kering Kecambah Normal (g) Benih Kedelai Kadaluarsa akibat Pengaruh Berbagai Jenis Ekstrak dan Konsentrasi ZPT Organik.

\begin{tabular}{llccc}
\hline \multicolumn{2}{c}{ Ekstrak } & \multicolumn{3}{c}{ Konsentrasi Ekstrak } \\
ZPT organik & $20 \%\left(\mathrm{~K}_{1}\right)$ & $40 \%\left(\mathrm{~K}_{2}\right)$ & $60 \%\left(\mathrm{~K}_{3}\right)$ \\
\hline Jagung & $\left(\mathrm{E}_{1}\right)$ & 12,15 & 12,95 & 12,75 \\
Tomat & $\left(\mathrm{E}_{2}\right)$ & 12,61 & 14,06 & 14,21 \\
Air kelapa $\left(\mathrm{E}_{3}\right)$ & 12,91 & 13,21 & 13,44 \\
\hline
\end{tabular}

Tabel 5 menunjukkan bahwa apabila menggunakan ekstrak jagung, berat kering kecambah normal benih cenderung lebih baik terdapat pada konsentrasi ekstrak $40 \%$, apabila menggunakan ekstrak tomat, berat kering kecambah normal benih cenderung lebih baik terdapat pada konsentrasi ekstrak 60\%, dan apabila menggunakan ekstrak air kelapa, berat kering kecambah normal benih cenderung lebih baik terdapat pada konsentrasi ekstrak $60 \%$, walaupun tidak berbeda nyata dengan perlakuan lainya. 


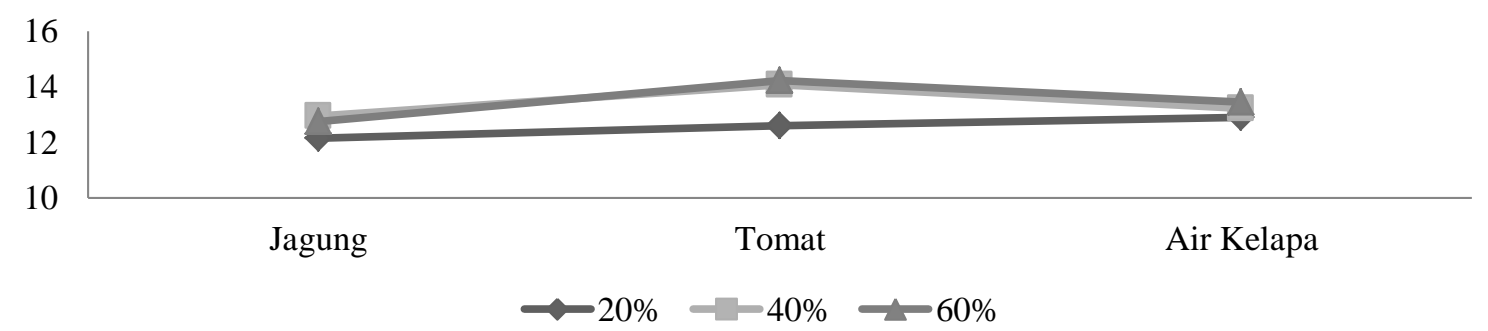

Gambar 4. Rata-tata Berat Kering Kecambah Normal (\%) Benih Kedelai Kadaluarsa akibat Pengaruh Berbagai Jenis Ekstrak dan Konsentrasi ZPT Organik.

Hasil penelitian yang telah dilakukan, (Tabel 1) menunjukkan bahwa perlakuanperlakuan yang diuji, baik secara mandiri maupun kombinasinya tidak berpengaruh nyata pada parameter-parameter yang diamati. Dapat dilihat pada semua tabel parameter diatas relatif tidak terjadi pengaruh yang nyata akibat penggunaan jenis ZPT organik dengan berbagai konsentrasi yang berbeda dalam peningkatan viabilitas benih kedelai kadaluarsa.

Pada parameter daya berkecambah, kecepatan tumbuh, dan keserempakan tumbuh nilai terbaik diperoleh pada perlakuan konsentrasi ekstrak jagung 20\%. Hal ini menunjukkan bahwa ekstrak jagung banyak mengandung karbohidrat serta auksin alami yang dapat merangsang pertumbuhan benih. Hal serupa dikemukakan oleh Damiska et al.(2015) karna ekstrak jagung muda mengandung asam amino, karbohidrat, vitamin, mineral, zat pengatur tumbuh auksin dan sitokinin untuk memenuhi unsur-unsur hara yang dibutuhkan tanaman.

Pada berat kering kecambah normal menunjukkan bahwa pemberian berbagai macam ekstrak ZPT organik dengan berbeda konsentrasi tidak mempengaruhi berat kering kecambah normal, sedangkan nilai tertinggi diperoleh pada perlakuan konsentrasi ekstrak tomat $60 \%$. Berat kering kecambah ialah hasil antara pengambilan karbondioksida (fotosintesis) dan pengeluaran karbondioksida (respirasi). Fotosintesis mengakibatkan meningkatnya berat kering kecambah akibat pengambilan karbondioksida, sedangkan pada proses katabolisme respirasi menyebabkan pengeluaran karbondioksida dan mengurangi berat kering kecambah (Gardner et al., 1991).

Faktor yang mempengaruhi viabilitas benih kadaluarsa adalah daya simpan benih dengan suhu dan kadar air yang optimal sehingga viabilitas benih tersebut masih terjaga. Menurut Justice dan Bass (2002), penyimpanan benih adalah suatu kondisi dimana benih ditempatkan pada suhu dengan kelembaban yang optimum agar benih bisa mempertahankan mutunya dari kerusakan fisiologisnya. Tujuan penyimpanan benih adalah untuk mengawetkan cadangan makanan didalam benih agar benih bisa bernilai ekonomis dari satu musim ke musim lainya.

\section{KESIMPULAN DAN SARAN}

\section{Kesimpulan}

Jenis ekstrak dan konsentrasi yang berbeda tidak berpengaruh nyata terhadap peningkatan viabilitas benih kedelai kadaluarsa. Pada parameter daya berkecambah, 
kecepatan tumbuh, dan keserempakan tumbuh nilai terbaik diperoleh pada perlakuan kombinasi konsentrasi ekstrak jagung 20\%, sedangkan berat kering kecambah normal pada ekstrak tomat $60 \%$. Terjadi interaksi yang tidak nyata akibat penggunaan jenis dan konsentrasi ekstrak ZPT organik pada semua parameter yang diamati.

\section{Saran}

Perlu dilakukan penelitian lebih lanjut dengan menggunakan zpt organik pada konsentrasi diatas $60 \%$.

\section{DAFTAR PUSTAKA}

Abidin, Z. 1993. Dasar-Dasar Tentang Zat Pengatur Tumbuh. Penerbit Angkasa. Bandung.

BPS. 2015. Produksi kedelai menurut provinsi (ton), 19932015. http://www.bps.go.id/linkTableDinamis/view/id/871(akses 17 maret 2018).

Damiska, S., R. S. Wulandari dan H. Derwati. 2015. Penambahan ragi dan ekstrak biji jagung terhadap pertumbuhan tunas manggis secara invitro. Hutan Lestari, 3(1): 3542.

Fatimah, S. N. 2008. Efektivitas air kelapa dan leri terhadap pertumbuhan tanaman hias bromelia (Neoregelia carolinae) pada media yang berbeda. Fakultas Keguruan dan Ilmu Pendidikan Universitas Muhammadiyah Surakarta.

Gardner FP, RB Pearce, RI Mitchell. 1991. Fisiologi tanaman budidaya. (Diterjemahkan oleh: Susilo H). Universitas Indonesia Press, Jakarta.

Gunawan, A. 2004. Invigorasi benih bengkuang (Pachyrrhizus erosus L.) kadaluarsa dengan teknik hydropriming menggunakan air kelapa muda dan pengaturan lama inkubasi. Skripsi. Fakultas Pertanian Universitas Syiah Kuala, Banda Aceh.

Halimursyadah., Hasanuddin., dan M.Nasution. 2003. Invigorasi benih hortikultura kadaluarsa melalui teknik organik priming. Fakultas Pertanian Universitas Syiah Kuala, Banda Aceh.

Halimursyadah., Jumini., dan Muthiah. 2015. Penggunaan organik priming dan periode inkubasi untuk invigorasi benih cabai merah (Capsicum annum L.) kadaluarsa pada stadia perkecambahan. J. Floratek. 10 (2): 78-86.

Hasanah, M. 2002. Peran mutu fisiologis benih dan pengembangan industri benih tanaman industri. Jurnal Litbang Pertanian, 21 (3) 84-91.

Hasbianto, A. 2012. Pemodelan penyimpanan benih kedelai pada sistem penyimpanan terbuka. Tesis. Institut Pertanian Bogor. 
Justice OL dan LN Bass. 2002. Prinsip dan praktek penyimpanan benih. Roesli R, penerjemah. Jakarta (ID): Grafindo Persada. Terjemahan dari: Principles and Practices of Seed Storage. 446 p.

Kartasapoetra, A,G. 2003. Teknologi Benih. Jakarta. PT. Rineka Cipta Raharja, P. C. 1998 Kultur jaringan teknik perbanyakan tanaman secara modern. Swadaya, Jakarta.

Miranda, C. D. 1999. Studi inkorporasi air kelapa (Cocoa nucifera) dalam proses matriconditioning dan tingkat vigor benih terhadap viabilitas benih kedelai (Glycine max L. (Merrill). Skripsi. Fakultas Pertanian Unsyiah Syiah Kuala, Banda Aceh.

Suhaeni, N. 2007. Petunjuk praktis menanam kedelai. NUANSA. Bandung.

Suwarno, F.C., dan I. Hapsari. 2008. Studi alternatif substrat kertas untuk pengujian viabilitas benih dengan metode uji UKDdp. Buletin Agronomi (36) (1) 84-91. 